Lenka LACINOVÁ ${ }^{1}$, Martina ČERNÍKOVÁ ${ }^{1}$, Jaroslav HRABAL $^{2}$ and Miroslav ČERNÍK ${ }^{1 *}$

\title{
IN-SITU COMBINATION \\ OF BIO AND ABIO REMEDIATION OF CHLORINATED ETHENES
}

\author{
POŁĄCZENIE METOD BIO- I ABIOREMEDIACJI IN-SITU \\ CHLOROWANYCH ETENÓW
}

\begin{abstract}
This article deals with combined abio-bioreductive methods for in-situ removal of chlorinated ethenes. The method is based on the use of bioremediation supported by lactate and chemical reduction using nZVI. The method is compared with the use of the individual methods alone, mainly with nZVI. In an environment with very low permeability a poor contaminant removal efficiency was achieved during repeated application of nZVI (about $50 \%$ of the original content of contamination). Separate application of lactate resulted in conversion of PCE to 1,2-cis-DCE, whose degradation occurred very slowly. When using the combined abio-bioreductive method, based on consecutive application of lactates and nZVI, over $75 \%$ of the original content of contamination was removed. This article discusses not only the changes in concentrations of contaminants but also $\mathrm{pH}$ and ORP. Both methods are also compared from an economic point of view.
\end{abstract}

Keywords: in-situ remediation, bioremediation, chlorinated ethenes, nZVI, reductive dehalogenation

\section{Introduction}

One of the reductive methods which have been recently intensively studied is the use of nanoparticles of zero-valent iron (nZVI) for in-situ reduction of contaminants [1-3]. nZVI easily reduce organic compounds such as chlorinated ethenes [4-8], chlorinated ethanes [9], chlorobenzenes [10], pesticides [3], PCB [11, 12]. Inorganic substances include several anions such as nitrate, phosphate and sulphate [3] and in particular heavy metals such as $\mathrm{Cr}$, $\mathrm{As}, \mathrm{Pb}$ and $\mathrm{U}[13-15]$ can be also stabilized by nZVI.

The mechanism of chlorinated hydrocarbons $(\mathrm{CHC})$ reduction by iron can be described by the reaction:

$$
\mathrm{Fe}+\mathrm{H}_{2} \mathrm{O}+\mathrm{RX} \rightarrow \mathrm{RH}+\mathrm{Fe}^{2+}+\mathrm{X}^{-}+\mathrm{OH}^{-}
$$

where $\mathrm{RX}$ and $\mathrm{RH}$ are halogenated and non-halogenated hydrocarbons, respectively.

\footnotetext{
${ }^{1}$ Technical University of Liberec, Studentská 2, 46117 Liberec 1, Czech Republic

${ }^{2}$ MEGA a.s., Drahobejlova 1452/54, Praha, Czech Republic

${ }^{*}$ Corresponding author: miroslav.cernik@tul.cz
} 
In this reaction iron is an electron donor, which removes chlorine atoms from the chlorinated hydrocarbon molecules. The exact mechanism of reaction is not known, two reaction pathways are assumed, sequential hydrogenolysis and $\beta$-elimination [16, 17]. During sequential hydrogenolysis the halogen elements in the hydrocarbons are gradually replaced by hydrogen to form halide and non-halogenated hydrocarbons. During $\beta$-elimination multiple bonds are formed between $\mathrm{C}$ atoms and halogen atoms are released.

Iron oxidizes in an aqueous environment both in the presence of oxygen and in its absence:

$$
\begin{aligned}
& \mathrm{Fe}^{0}+1 / 2 \mathrm{O}_{2}+\mathrm{H}_{2} \mathrm{O} \rightarrow \mathrm{Fe}^{2+}+2 \mathrm{OH}^{-} \\
& \mathrm{Fe}^{0}+2 \mathrm{H}_{2} \mathrm{O} \rightarrow \mathrm{Fe}^{2+}+2 \mathrm{OH}^{-}+\mathrm{H}_{2}
\end{aligned}
$$

During the application of nZVI to the rock environment there is a strong decrease in redox potential to a value of $-500 \mathrm{mV}$ and an increase in $\mathrm{pH}$ to 10 depending on the natural buffering capacity of the rock environment.

The first iron nanoparticles were synthesized in the 1990s by the so-called wet method at Lehigh University in the USA [2,3]. Laboratory tests have so far proven their effectiveness for the reduction of more than 70 different compounds [3]. The disadvantage of this method is the high price of agents and the limited migration of nZVI in the aquifer.

The second recently used reductive technology is reductive bioremediation. The principle of biological methods is generally that microorganisms utilize contaminants as a source of energy or nutrients. These processes run by themselves as natural attenuation [18]. It is possible, however, to significantly intensify infiltration using an easily fermentable substrate (electron donor or acceptor, nutrients etc.). The most commonly used substrates are lactate, molasses, vegetable oil, whey powder, ethanol and others [19, 20]. Their fermentation leads to the release of hydrogen (electron donor) and the formation of a reductive environment.

There are a number of dehalorespiration bacteria of the genus Desulfitobacterium, Dehalobacter, Clostridium, Dehalospirillum and Dehalococcoides, capable of degrading chlorinated hydrocarbons [21, 22]. Microbial dehalogenation occurs as a sequential decomposition in which there is a gradual elimination of chlorine atoms in the steps: $\mathrm{PCE} \rightarrow \mathrm{TCE} \rightarrow$ 1,2-cis-DCE $\rightarrow$ vinyl chloride $(\mathrm{VC}) \rightarrow$ ethane. Each subsequent step requires a lower redox potential than the previous step. The disadvantage of microbial dehalogenation is slower degradation of contaminants and the common accumulation of toxic intermediates such as 1,2-cis-DCE and VC [23].

Several studies have been published on the combination of both methods [24-28], which leads to an increase the effectiveness of remediation and elimination of the negatives of the individual methods. The aim of this study is to compare the effectiveness and costs of the method combined lactate and nZVI with individual methods on a site contaminated with chlorinated ethenes. The pilot location is the Karbox site in Horice v Podkrkonosí, Czech Republic.

\section{Methodology}

\section{Geological and hydrogeological site settings}

The site belongs to the Czech Cretaceous Basin - Horice anticline. Cretaceous sediments are represented by rocks of the Cenomanian and Lower Turonian. The thickness 
of the Weissenberg Formation (Turonian) is reduced towards the core of the anticlines by denudation until its complete disappearance. The situation is complicated by tectonics, with vertical displacement of the blocks. The Quaternary is composed by loess and loess loams to a thickness of about $6 \mathrm{~m}$, separated from the Turonian layer by redeposited sandy-silty clays of a varied composition.

Hydrologically the most important is the Cenomanian aquifer. It is an artesian aquifer with intrinsic-fissure permeability and a coefficient of transmissivity of up to $10^{-3} \mathrm{~m}^{2} \mathrm{~s}^{-1}$. The main groundwater flow direction is to the SW and the aquifer is used for supplying drinking water to the town of Horice. Another aquifer is Turonian, which lies in a zone of weathered Turonian sediments and has fissure permeability with a coefficient of transmissivity of $10^{-5} \mathrm{~m}^{2} \mathrm{~s}^{-1}$. The aquifer is recharged mainly by overflow between the Turonian and Cenomanian aquifers. The uppermost is a shallow Quaternary aquifer, which is bound to the Quaternary sediments of very low transmissivity (in the order of $10^{-6} \mathrm{~m}^{2} \mathrm{~s}^{-1}$ ) [29].

The groundwater chemistry is different in the Cenomanian and the other two aquifers (Turonian and Quaternary). The water of the Cenomanian aquifer is of $\mathrm{Ca}-\mathrm{HCO}_{3}$ type, slightly acidic, with total mineralization of $250 \mathrm{mg} \cdot \mathrm{dm}^{-3}$ and a high $\mathrm{Fe}$ content. The groundwater of the Quaternary and Turonian aquifers is of $\mathrm{Ca}-\mathrm{HCO}_{3}-\mathrm{SO}_{4}$ type, neutral to slightly alkaline, with higher mineralization $\left(600-1,200 \mathrm{mg} \cdot \mathrm{dm}^{-3}\right)$ and low Fe content [29].

\section{The extent of contamination prior to in-situ remediation}

Due to the mismanagement of industrial production the groundwater below the site was contaminated with chlorinated ethenes and total petroleum hydrocarbons (TPH). Remediation began during the 1990s when contaminated soil was excavated from the centre of the contamination and soil gas venting and groundwater pumping methods were applied. This led to the achievement of remedial target levels for TPH only, the content of chlorinated ethenes remained significantly above the threshold.

The main contaminants at the site prior to in-situ remediation were chlorinated aliphatic hydrocarbons. Five contamination hotspots were identified in total, which are greatly extended in the groundwater flow direction due to the geological structures. Before the start of the presented activities the maximum concentrations of the sum of chlorinated ethenes in groundwater were around 60 and $10 \mathrm{mg} \cdot \mathrm{dm}^{-3}$ (predominantly PCE) for the Quaternary and Turonian horizon, respectively. The pilot applications took place in the two selected hotspots (labelled COMBI for the combined method of lactate and nZVI and NANO for the application of nZVI only) in order to avoid the potential influence of the individual remedial actions.

\section{Remediation}

In the spring of 2008 pilot applications (application A1) of the nZVI (NANOFER 25S, NANO IRON, Czech R.) at the hotspot NANO and sodium lactate at COMBI took place. Subsequently in the period from 2008 to 2010 a total of 3 rounds of operational remediation using nZVI (application A2-A4) were performed.

Cased wells ending at a depth of $10 \mathrm{~m}$ (above the base of the Quaternary) were planned to be used during the pilot application for the injection of agents. Gravitational injection of 
sodium lactate took place in April 2008 (month 3) in 9 wells in the COMBI hotspot. Simultaneously nZVI was injected to 9 wells in the NANO hotspot by pressurized injection.

Operational application using only nZVI on both hotspots took place in three rounds in October 2008 (A2), October 2009 (A3) and October 2010 (A4). Based on the experiences from the pilot test, nZVI was applied in about 20 injections by the direct-push method. Remedial monitoring was performed for the entire duration of the remediation to determine concentrations of chlorinated ethenes, $\mathrm{pH}$ and ORP.

\section{Results}

pH

In the NANO hotspot there was observed an increase in $\mathrm{pH}$ of about 1.5 units to values of 8.5 to 9 after each round of nZVI application, and most in the application wells, with a very similar course in the Quaternary and Turonian observation wells (Fig. 1a). The pH values then gradually returned to normal. The maximum increase in $\mathrm{pH}$ was determined after the last round of infiltration (A4). Changes after application A3 in relation to the application at the edge of the hotspot were less pronounced.

a)

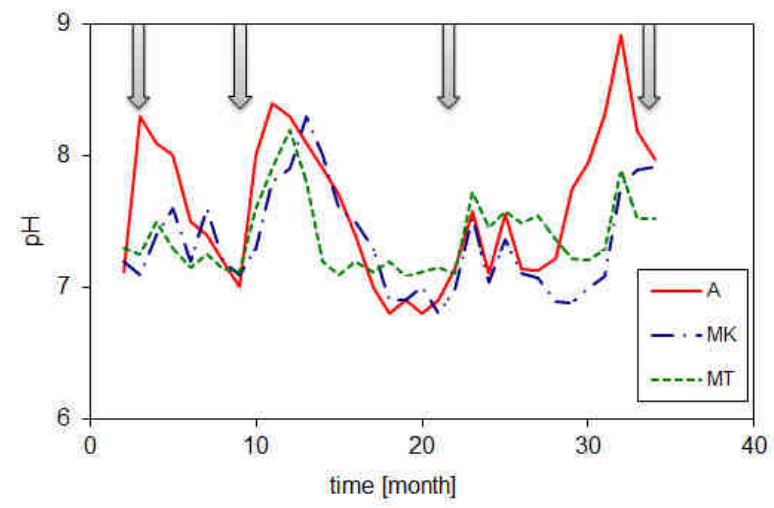

b)

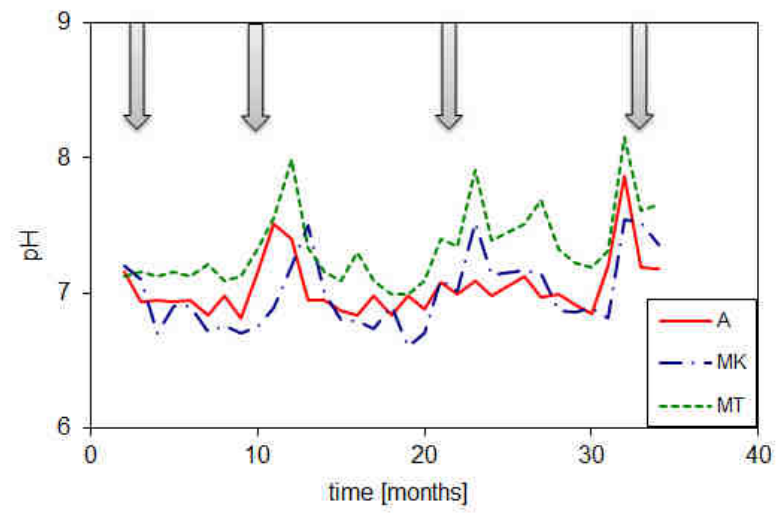

Fig. 1. Changes on $\mathrm{pH}$ in: a) the NANO and b) COMBI hotspots (average values for A - Application wells, MK - Quaternary monitoring wells, MT - Turonian monitoring wells). Arrows label applications A1-A4 
In the hotspot with the combined method (COMBI) there was a decrease in $\mathrm{pH}$ in the application and Quaternary monitoring wells after the pilot application of sodium lactate. The operational application of nZVI revealed, as in the NANO hotspot, an increase the $\mathrm{pH}$ of about 1.5 to values of around $\mathrm{pH} 8$, with the greatest change being in the Turonian well.

\section{ORP}

In the NANO hotspot, the maximum change in ORP values was observed in the application wells, which was caused by direct contact between groundwater and nZVI. The ORP values decreased to an average of $-500 \mathrm{mV}$ after application $\mathrm{A} 1$, then the values increased but after a period of about 6 months the measured values of ORP were still negative (Fig. 2).

a)

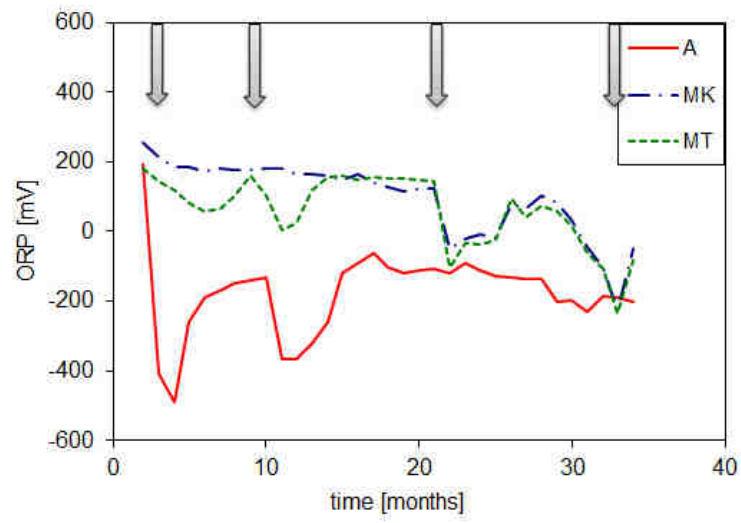

b)

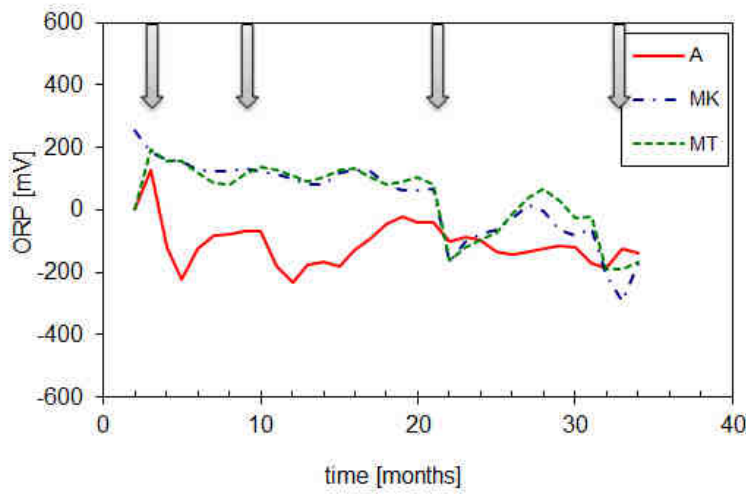

Fig. 2. Changes on ORP in: a) the NANO and b) COMBI hotspots (average values for A - Application wells, MK - Quaternary monitoring wells, MT - Turonian monitoring wells)

After the first operational application of nZVI (A2), which took place beyond these wells, ORP values decreased again to an average of $-400 \mathrm{mV}$ and then slowly increased. Further applications of nZVI showed no significant change in ORP; however, slightly reducing or anoxic conditions remained in the wells. In the COMBI hotspot, the maximum change of ORP was also seen in the application wells, the initial decrease to $-200 \mathrm{mV}$ was 
due to direct contact between the groundwater and sodium lactate in the wells, the ORP value then gradually increased to approximately $-100 \mathrm{mV}$. During application A2, beyond these wells, ORP values were observed to decrease again to an average of $-200 \mathrm{mV}$, further application of nZVI showed only minor changes in ORP (by about 150 and $100 \mathrm{mV}$ ). Anoxic conditions remained in the wells. A considerable decrease in observation wells after $\mathrm{A} 3$ and A4 is probably due to the wider range of the applications over a larger area.

\section{Chlorinated ethenes}

The overall efficiency of the removal of chlorinated ethenes in the hotspot with the combined method was demonstrably better than in the hotspot with nZVI only. Compare 86, 64 and $80 \%$ of the original content of chlorinated ethenes removed for COMBI to 77, 24 and $40 \%$ for NANO in the application wells, the Quaternary wells and the Turonian wells, respectively.

Generally speaking, the effect of the second application of nZVI (A3) on the decrease in concentrations of chlorinated ethenes was less in both hotspots. Applications took place on the edges of the hotspots and tended to reduce the extent of the contaminated area.

a)

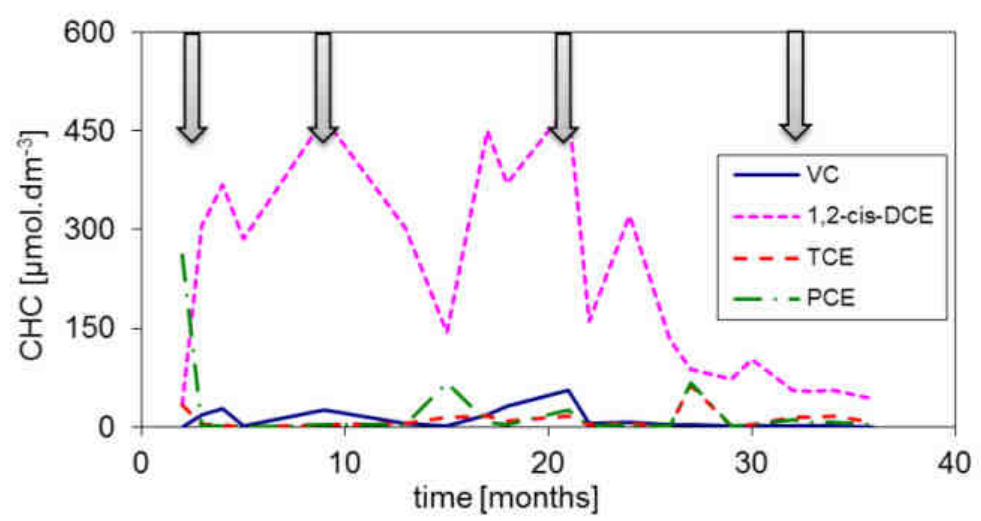

b)

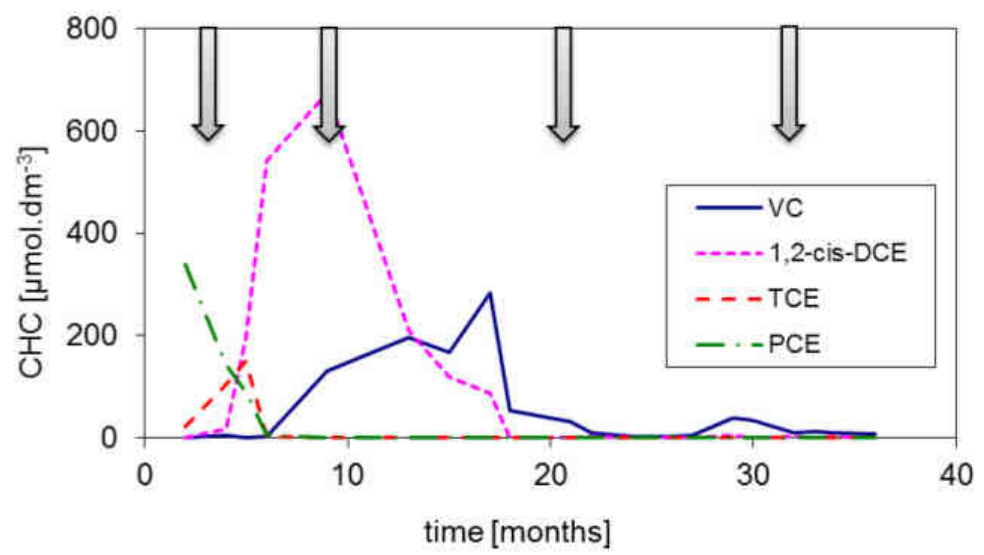

Fig. 3. Examples of the removal mechanisms for chlorinated hydrocarbons in: a) the NANO and b) COMBI hotspots 
Figure 3 compares examples of degradation of chlorinated ethenes in selected application wells which best illustrate the different mechanisms of dechlorination. The graph shows more direct decomposition of chlorinated ethenes for the application well in the NANO hotspot. PCE and TCE were degraded almost immediately, whilst degradation of 1,2-cis-DCE took place very slowly and VC was detected at very low concentrations. The graph shows the rapid sequential degradation of chlorinated ethenes for the application well in the COMBI hotspot: a consecutive decrease of PCE, postponed increase and decrease in TCE, 1,2-cis-DCE and VC with a peak at 5, 9 and 17 months.

The largest difference between the two methods is in the degradation of 1,2-cis-DCE, where in the case of nZVI multiple infiltrations were required, while in the case of the combination of methods degradation fulfilled after the first application of nZVI (A2).

\section{Comparison of the effectiveness in the hotspots for each round of application}

The largest decrease of chlorinated hydrocarbons was recorded in the application wells, a smaller decrease of chlorinated ethenes was observed in the Turonian observation wells, the least affected were the Quaternary observation wells (Table 1). This is given by a very low groundwater flow rate in the Quaternary aquifer and thus very limited migration of applied agents.

Table 1

Comparison of final concentrations of $\mathrm{CHC}$ during the remedial action

\begin{tabular}{|c|c|c|c|c|c|}
\hline \multirow{3}{*}{ Hotspot } & \multirow{3}{*}{ Well type } & \multirow{2}{*}{$\begin{array}{c}\text { Pilot } \\
\text { application } \\
\text { (A1) }\end{array}$} & \multicolumn{3}{|c|}{ Remediation } \\
\hline & & & A2 & A3 & A4 \\
\hline & & $\mathrm{CHC}(\%)$ & $\mathrm{CHC}(\%)$ & $\mathrm{CHC}(\%)$ & $\mathrm{CHC}(\%)$ \\
\hline \multirow{3}{*}{ NANO } & $\mathrm{A}$ & 102.6 & 159.9 & 30.4 & 22.7 \\
\hline & MK & 161.9 & 105.2 & 94.9 & 76.1 \\
\hline & MT & 80.6 & 73.7 & 112.0 & 59.5 \\
\hline \multirow{3}{*}{ COMBI } & $\mathrm{A}$ & 157 & 12.4 & 13.7 & 13.7 \\
\hline & MK & 110.6 & 74.4 & 72.8 & 36.5 \\
\hline & MT & 129.3 & 76.8 & 19.5 & 20.7 \\
\hline
\end{tabular}

A - application well, MK - monitoring Quarternary well, MT - monitoring Turonian well, CHC - total chlorinated hydrocarbon concentration in respect to the original values

A greater efficiency in the degradation of chlorinated hydrocarbons was achieved in the COMBI hotspot. After an initial increase in the concentration of ethenes, caused by rinsing of the unsaturated zone after the application of lactate A1, there was a clear and steady decline of chlorinated hydrocarbons in all of the monitoring wells. In the application wells there was a steady decline immediately after the first application of nZVI (A2), in the Turonian monitoring wells this occurred after the second nZVI application (A3) and in the Quaternary wells after the third application of nZVI (A4). Significantly worse situation was determined for NANO hotspot. The increase in the concentration of ethenes lasted to A2 injection for the application wells and decreases are significantly slower.

\section{Economic comparison of methods}

In addition to monitoring the effectiveness of the degradation of chlorinated hydrocarbons, both methods were compared from an economic point of view. Through 
small differences in every injection process, all applications of nZVI were very similar and therefore one nZVI application scenario was financially evaluated and used for the economic analysis. This uniform nZVI application represents direct-push injection of $3 \mathrm{~g} \cdot \mathrm{dm}^{-3} \mathrm{nZVI}$ solution in water in the depth of about 10 meters. Eighty kg of nZVI was applied $\left(26 \mathrm{~m}^{3}\right.$ of solution) into about 20 injection points. Overall penetration depth and time with a speed of $0.5 \mathrm{~m}^{3}$ injected per hour was $260 \mathrm{~m}$ and 50 hours, respectively. The total time including transport, installation and decommissioning of injection technology was 7 days. The costs of nZVI injection are summarized in Table 2. For the first injection, where the application was realized into 9 wells with smaller amount of nZVI, one half of the cost was taken.

Overview of nZVI injection

\begin{tabular}{|c|c|c|c|}
\hline Item & Number of units & Unit cost & Cost [thousand $€$ ] \\
\hline nZVI & $80 \mathrm{~kg}$ & $100 € / \mathrm{kg}$ & 8 \\
\hline direct push & $260 \mathrm{~m}$ & $15 € / \mathrm{m}$ & 4 \\
\hline operational costs & 50 hours & $80 € / \mathrm{h}$ & 4 \\
\hline personal costs & 1 month & $2,000 € / \mathrm{month}$ & 2 \\
\hline management & 1 & $1,000 €$ & 1 \\
\hline sum nZVI & & & 19 \\
\hline
\end{tabular}

In case of more mobile lactate, the application was provided by pressurized injection into 10 wells of the same depth. Lactate concentration was $10 \mathrm{~g} \cdot \mathrm{dm}^{-3}$, meaning that $100 \mathrm{~m}^{3}$ of solution was injected. Total application time was approximately similar of 50 hours (Table 3).

Overview of lactate injection

Table 3

\begin{tabular}{|c|c|c|c|}
\hline Item & Number of units & Unit cost & Cost [thousand $€$ ] \\
\hline lactate & $1000 \mathrm{~kg}$ & $1.4 € / \mathrm{kg}$ & 1.4 \\
\hline well installations & $100 \mathrm{~m}$ & $60 € / \mathrm{m}$ & 6 \\
\hline operational costs & 50 hours & $80 € / \mathrm{h}$ & 4 \\
\hline personal costs & 1 month & $2 \mathrm{k} € / \mathrm{m}$ & 2 \\
\hline management & 1 & $1 \mathrm{k} €$ & 1 \\
\hline sum lactate & & & 14.4 \\
\hline
\end{tabular}

Comparison is based on measurement of $\mathrm{CHC}$ concentration in quaternary wells, where decrease of concentration after lactate and first nZVI application (COMBI) is comparable to decrease observed after 4th injection of nZVI in case of straight nZVI application (NANO). Economically 33,400 $€$ for COMBI (Fig. 4), calculated as one lactate plus one nZVI application, was compared to $66,500 €$ for nZVI application cost (3.5 times nZVI application). The overall cost (excluding monitoring) for the combined method was about one half of the one for pure nZVI remediation to achieve similar results. 


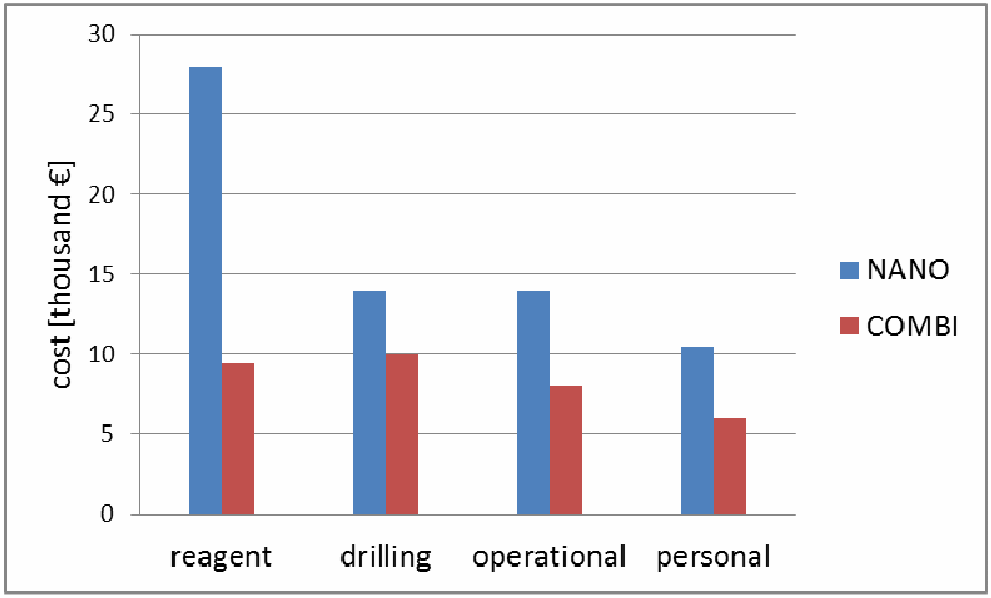

Fig. 4. Economic comparison of the technologies

\section{Discussion}

The site in Horice v Podkrkonosí was the first location in the Czech Republic where operational remediation was carried using a new type of elemental nZVI NANOFER 25S (NANO IRON s.r.o.). At the site of the industrial enterprise KAR-BOX there are five hotspots of chlorinated hydrocarbon contamination affecting the Quaternary and Turonian aquifers. The maximum levels of chlorinated ethenes were in order of $10 \mathrm{mg} \cdot \mathrm{dm}^{-3}$, with the predominant hydrocarbon being PCE. The uniqueness of the site lies in the very low permeability of the rock environment with a coefficient of transmissivity in the order of $10^{-6} \mathrm{~m}^{2} / \mathrm{s}$.

The repeated application of nZVI was carried out to remediate one of the main hotspots at the site (NANO). During the pilot test it was determined that the planned infiltration to cased wells was not possible due to low hydraulic conductivity of the aquifer and overpressure resulting in seepage of the reagent to the surface. NZVI was further applied by using the direct-push method. The efficiency of the remediation was not very high, on average only around $48 \%$ of the original content of contamination was removed. In the Turonian observation wells the efficacy was higher than in the Quaternary wells, the maximum efficiency was achieved in the original application wells.

During the remediation of the second most important hotspot, a combination of two remediation methods was used - biologically supported dehalogenation using sodium lactate and chemical reduction using nZVI (COMBI). Sodium lactate was applied in this hotspot into cased wells during the pilot test. This was followed by a total of 3 rounds of remedial application of nZVI (in 2008, 2009 and 2010). There was a clear increase in the efficiency of degradation of chlorinated hydrocarbons after the first round of nZVI application in this hotspot. After the third round an average of $76 \%$ of the initial contamination levels was removed in all of the monitored wells.

After evaluating the data from the site, whose uniqueness lies in the very low permeability of the rock environment, the results of the remediation can be summarized as follows: When nZVI was used alone the efficiency was low, even repeated application of 
the agents did not produce the desired effect mainly due to the limited groundwater flow and thereby the rock environment only being influenced in the immediate vicinity of the application wells. The efficiency of removal of chlorinated ethenes after the first round of remediation using the combined abio-bio-reductive method (sequential application of a biological substrate and nZVI) was comparable to the third round of remediation in the nZVI hotspot. This is due to both to facilitating the spread of lactate and also the different principle of action on the substrate. The substrate does not have to be applied in direct contact with the contaminant, the dehalogenation microorganisms are affected in a much wider spatial range. The combined method is thus a very promising remediation method in rock formations with low permeability.

\section{Conclusions}

This study describes and compares two in-situ remediation methods for CHC remediation: in-situ reductive dehalogenation by nano-scale zero valent iron NANOFER and a combination of microbial reductive dehalogenation, supported by lactic acid, and reduction by nZVI. The full-scale applications of both methods were performed simultaneously in separate hotspots during the remediation of the Horice site characterized by a very low hydraulic conductivity.

In the nZVI hotspot ORP decreased immediately to $-500 \mathrm{mV}$ in the application wells compare to about $-200 \mathrm{mV}$ in the combined method hotspot. Similarly, pH increased by about 1.5 in the application wells of nZVI compare to a decrease by about 0.5 after lactate injection. The efficiency of $\mathrm{CHC}$ reduction was significantly better in the combined method hotspot. On average, $76 \%$ of the initial $\mathrm{CHC}$ concentration was reduced in the combined method hotspot and $48 \%$ of initial CHC concentration in the nZVI hotspot. The determined mechanisms of the $\mathrm{CHC}$ elimination were also different. In the combined method hotspot sequential $\mathrm{CHC}$ dehalogenation with production of vinylchloride was observed compare to direct 1,2-cis-DCE removal in case of nZVI application. The economic comparison shows about one half of the cost of the combined method compare to pure nZVI remediation for similar remediation effect. The combined abio-bio-reductive method seems to be a very promising remediation method in aquifers with low permeability.

\section{Acknowledgements}

The article was partly supported by the OP R\&DI project Centre for Nanomaterials, Advanced Technologies and Innovation CZ.1.05/2.1.00/01.0005 and partly by the competence center TE01020218.

\section{References}

[1] Mueller NC, Nowack B. Nano zero-valent iron - THE solution for water and soil remediation? Report of the Observatory NANO 2010. [online]. [cit. 25.2.2013]. Available from http://www.observatorynano.eu/project/filesystem/files/nZVI_final_vsObservatory.pdf

[2] Zhang W, Elliot DW. Remediation. 2006;16(2):23. DOI: 10.1002/rem.20078.

[3] Zhang WX. J Nanoparticle Res. 2003;5(3-4):323-332.

[4] Arnold W, Roberts L. Environ Sci Technol. 2000;34:1794-1805. DOI: 10.1021/es990884q.

[5] Lien H, Zhang W-X. Colloid Surfaces. 2001;191:97-105. DOI: 10.1016/S0927-7757(01)00767-1.

[6] Phenrat T, Saleh N, Sirk K, Tilton R, Lowry G. Environ. Sci Technol. 2007;41:284-290. DOI: 10.1021/es061349a. 
[7] Liu Y, Majetich SA, Tilton RD, Sholl DS, Lowry GV. Environ Sci Technol. 2005;39:1338-1345, DOI: 10.1021/es049195r.

[8] Song H, Carraway ER. Appl Catalysis B: Environmental. 2008;78:53-60. DOI: 10.1016/apcatb.2007.07.034.

[9] Song H, Carraway ER. Environ Sci Technol. 2005;39:6237-6245. DOI: 10.1021/es048262e.

[10] Xu Y, Zhang W. Ind Eng Chem Res. 2000;39(7):2238-2244. DOI: 10.1021/ie9903588.

[11] Chuang FW, Larson RA, Wessman MS. Environ Sci Technol. 1995;29:2460-2463. DOI: $10.21 / \mathrm{es} 00009 \mathrm{a} 044$.

[12] Wang C, Zhang W-X. Environ Sci Technol. 1997;31:2154-2156. DOI: 10.1021/es970039c.

[13] Dries J, Bastiaens L, Sringael D, Agathos SN, Diels L. Environ Sci Technol. 2005;39:8460-8465. DOI: 10.1021/es050251d.

[14] Kanel SR, Manning B, Charlet L, Choi H. Environ Sci Technol. 2005;39:1291-1298. DOI: 10.1021/es048991u.

[15] Ponder SM, Darab JG, Mallouk TE. Environ Sci Technol. 2004;34:2564-2569. DOI: 10.1021/es9911420.

[16] Liu Y, Lowry GW. Environ Sci Technol. 2006;40:6085-6090. DOI: 10.1021/es0606850.

[17] Karn B, Kuiken T, Otto M. Environ Health Perspectiv. 2009;117:1823-1831. DOI: 10.1289/ehp.0900793.

[18] Wiedermeier TH, Rifai HS, Newell CJ, Wilson JT. Natural Attenuation of Fuels and Chlorinated Solvents in the Subsurface. New York: John Willey \& Sons; 1999.

[19] DiStefano TD, Gosset JM, Zinder SH. Appl Environ Microb. 1992;58:3622-3629.

[20] Fennel DE, Gossett JM, Zinder SH. Environ Sci Technol. 1997;31:918-926. DOI: 10.1021/es960756r.

[21] Amos BK, Suchomel EJ, Pennel KD, Löffler FE. Water Res. 2008;42:2963-2974. DOI:10.1016/j.watres.2008.03.15.

[22] Maymó-Gatell X, Anguish T, Zinder SH. Appl Environ Microb. 1999;65:3108-3113.

[23] Cupples AM, Spormann AM, McCarty PL. Environ Sci Technol. 2004;38:1102-1107. DOI: 10.1021/es0348647.

[24] Lampron J, Chiu PC, Cha DK. Bioremed J. 1998;2:175-181. DOI: 10.1080/10889869809380375.

[25] Lampron J, Chiu PC, Cha DK. Water Res. 2001;35:3077-3084. DOI: 10.1016/S0043-1354(01)00017-3.

[26] Fernandez-Sanchez JM, Sawvel EJ, Alvarez PJJ. Chemosphere. 2004;54:823-829. DOI: 10.1016/j.chemosphere.2003.08.037.

[27] Wang SM, Tseng SK. Biores Technol. 2008;100:111-117. DOI: 10.1016/j.biortech.2008.05.003.

[28] Rosenthal H, Adrian L, Steiof M. Chemosphere. 2004;55:661-669. DOI: 10.1016/j.chemosphere.2003.11.053.

[29] Ondra E. Actualized risk assessment of old environmental liabilities in Karbox. (Aktualizace analýzy rizika starých ekologických zátěží v areálu Karbox), Hořice: Kar-Box, s.r.o.; 2006.

\title{
POŁĄCZENIE METOD BIO- I ABIOREMEDIACJI IN-SITU CHLOROWANYCH ETENÓW
}

\begin{abstract}
Abstrakt: Przedstawiono metodę abio-bioredukcji usuwania in-situ chlorowanych etenów. Metoda ta polega na połączeniu bioremediacji, wykorzystującej redukcję mleczanu, i metody chemicznej nZVI. Wyniki tych badań porównano z danymi otrzymanymi z wykorzystaniem jedynie metody chemicznej. W środowisku o bardzo małej przepuszczalności uzyskano stosunkowo niską skuteczność usuwania zanieczyszczeń podczas wielokrotnego stosowania nZVI (około 50\% pierwotnej zawartości zanieczyszczeń). Oddzielna aplikacja mleczanu spowodowała konwersję PCE do 1,2-cis-DCE, którego degradacja następowała bardzo powoli. Przy użyciu połączonej metody abio-bioredukcji, opartej na stosowaniu kolejno mleczanów i nZVI, usunięto ponad 75\% pierwotnej zawartości zanieczyszczeń. W artykule omówiono nie tylko zmiany w stężeniu zanieczyszczeń, ale również pH i ORP. Oba sposoby porównano również pod względem ekonomicznym.
\end{abstract}

Słowa kluczowe: remediacja in-situ, bioremediacja, chlorowane eteny, nZVI, dehalogenacja redukcyjna 